\title{
The Impact of COVID-19 Pandemic on Factors Influencing Consumer Behaviour: A Study with Reference to Bengaluru (U)
}

\author{
Ajatashatru Samal' ${ }^{1}$ Rajeshwari G.V² and Sunitha Y.K ${ }^{3}$ \\ ${ }^{1}$ Department of Master of Business Administration, Sri Venkateshwara \\ College of Engineering, Bengaluru, India \\ ${ }^{2}$ Department of Master of Business Administration, Nagarjuna College of \\ Engineering and Technology, Bengaluru, India \\ ${ }^{3}$ Department of Master of Business Administration, Sri Venkateshwara College of \\ Engineering, Bengaluru, India
}

\section{ABSTRACT}

Corona virus impact has been felt around the world and a new normal has emerged which is inevitable with the arrival of Virus (Covid-19). The pandemic has disrupted life as we know it, so is its impact on lifestyle, health and consequently the consumer behaviour as well. Disruption is seen in the economic, social processes and systems as well. The newer needs, behaviours and orientations are contributing to shaping of a new cohort for businesses. However, this development is not recognised to be a temporary or a permanent phenomenon. While still the fear of pandemic is lingering around, it is crucial for the businesses to assess the altered or changing attitudes and behaviours of the urban consumers. Convenient sampling technique has been adopted as far as data collection is considered. The study reveals that the pandemic has created a shift in buying behaviour of consumers while at the same time creating disruptions in the existing supply chain. The purchasing behaviour is more driven towards essentials, health products and locally available products while the brand consciousness has taken a step back. A new normal is inevitable where everyone has to learn to live with the existing reality ultimately leading to lasting structural changes in businesses.

\section{KEY WORDS: CONSUMER BEHAVIOUR, SATISFACTION, DISRUPTION, IMPACT, SPENDING INTENT.}

\section{INTRODUCTION}

The world has witnessed an unpredictable pandemic of its kind in Covid-19. This has disrupted the business models, life style, thinking patterns, learning methodologies and what not (Arun et al. 2020). Many businesses have found this disruption an opportunity to change while many of them have perished silently (Prabu et al, 2020). The main

\section{ARTICLE INFORMATION}

*Corresponding Author: rajisuma@gmail.com

Received 12th Oct 2020 Accepted after revision 28th Dec 2020

Print ISSN: 0974-6455 Online ISSN: 2321-4007 CODEN: BBRCBA

Thomson Reuters ISI Web of Science Clarivate Analytics USA and Crossref Indexed Journal

\section{Clarivate
Analytics}

NAAS Journal Score 2020 (4.31)

A Society of Science and Nature Publication,

Bhopal India 2020. All rights reserved.

Online Contents Available at: http//www.bbrc.in/

Doi: http://dx.doi.org/10.21786/bbrc/13.13/31 factor detrimental is the demand creation which is always induced at the consumers end. So, what has changed at the end consumer end which is affecting the businesses that have existed for a longer time to wither against this uncertainty. Hence it becomes imperative to understand the behaviour that influences the behaviour of consumer which shapes the businesses models disruptions (Philip Kotler 2019).

With the onset of the pandemic, we have been witnessing lower incomes and an unexpressed dissatisfaction towards shrinking economy, which has made the Indian consumers to cut back purchases on categories like travel, recreation, entertainment, apparels etc. the focus is more on keeping purchases limited to only groceries and other house hold supplies. with each passing day, living with the virus, majority of the consumers in India have adopted a new minimalistic shopping behaviour (Thich, 2019). Now,

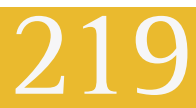


shopping online has been adopted as an inevitable way of finding a balance in the new normal. As safety becomes the first priority, new habits are being formed which is here to stay permanently. This change is affecting the Indian consumers value system, the way of shopping, the way of living and working. The retail revolution in India has changed the buying behaviour of the customer (Swati Vijay, 2015). So, it is necessary to document the changing behaviours which shall drive the sales for the companies at large.

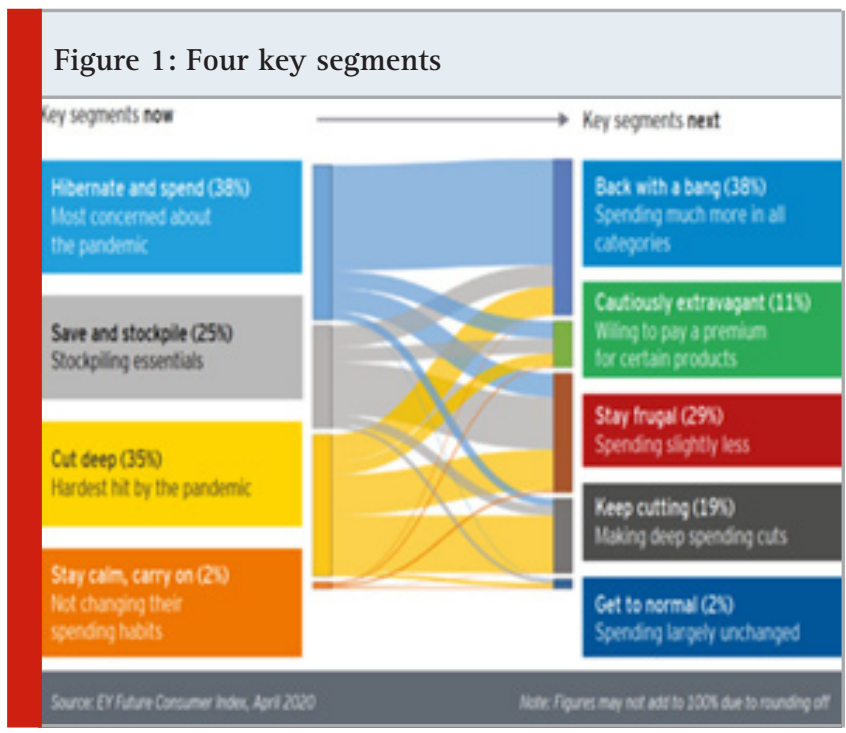

In India, economic and social changes are major contributors for dividing into multiple segments and their buying priorities (George Baltas et al. 2012). The present competitive market is full of me-too products. Therefore, it is absolutely essential that marketers should understand the uniqueness of behaviour and make product or service offering accordingly (Suja R. Nair 2013). In India, the pandemic has started to radically change the consumer behaviour (EY Future Consumer Index, June 2020). The distinct behaviour segments observed in urban areas are - Hibernate - Spend, Cut Deep, Save - Stockpile and Stay Calm - Carry 0n. An insignificant percentage of consumers are least impacted from the pandemic and are not changing their old spending habits. In this time of uncertainty, owing to the fragility in ways of doing business and given the expected changes in consumer behavior, marketers need to devise and implement actions quickly so as to respond to the NOW phase of business. This will help alter the operating business model which will address the NEXT phase of business and then they can consider the strategies to build a resilient structure for the BEYOND phase.

As the demand for local is echoing higher and higher, majority of the consumers are already making rapid and drastic changes in the way they want to live, rejuvenate, work and shop. These changes are expected to last longer post crisis and the probability of consumers reassociation with the earlier brands before pandemic is less. In a way, Covid-19 is probable to make the altered consumer behavior permanent (Accenture-COVID19 - Pulse Survey - Research -PoV.pdf, April 2020). Brands need to be more cautious in exploring newer ways of rebuilding consumer confidence tattered by the pandemic.

Digital adoption is here to stay (Anupama Sharma,2020). With the virus, comes one of the biggest digital waves - be it entertainment, financial transaction, purchases, social interaction or integration of class room learning with distance. Online will be the new dominant channel in the New Normal. Shopping online, greater media consumption (Netflix, Amazon Prime, Hotstar), home delivery of food (Swiggy, Zomato, Amazon) and groceries (Big basket, Amazon, Flipkart, Grofers), work from home, EdTech startups - virtual tutoring, online education apps, Meditation apps - Headspace, Unmind etc. All these indicates customers resorting to safer ways of indulging in daily tasks. This clearly tells us that marketers should well understand what, why, when, where and how frequently and so on questions relating to the consumers purchases and consumer behaviour. Marketers should follow the positivism theory which stipulates that if marketers predict correctly the consumer behaviour then they can influence behavior. They must be equipped to retort to newer habits which consumers develop after having lived through the pandemic.

\section{MATERIAL AND METHODS}

Review of Literature: Reisman et al., 1950, Linder 1970, Putnam 2000 all have stated that one should anticipate dramatic changes in consumer behaviour as a consequence of speedier and universal adoption of new technologies accelerated by the pandemic. Philip Kotler (2019) through his commentary titled "The Market for Transformation", states that consumers in present times look out continuously for hope, remedies and anchors which can alter the persona by which they see value being transformed. Jagdish Sheth (2020) examined that consumer consumption is habitual but also contextual. Social, Technology, Rules \&t Regulations and Ad hoc natural disasters - the four major contexts that potentially disrupt consumer habits. Lockdown and social distancing also have led to significant disruptions on consumer behavior.

Global Web Index (2020) in its study on impact of corona virus showcases higher growth rates of digitalization. In the study aimed to understand the Indian consumers purchasing behaviour (Covid-19 time), Majority (60\%) of the respondents were found to purchase online because of free delivery and reliability and agreed to spend significant time online researching the brands or products they intend to purchase. Thich (2019) explains the spiritual dimension in consumer behaviour. Consumers are beginning to stop consuming in their habitual ways by discarding what they do not need. Anupama Sharma (2020) feels that online players are working continuously in making it easy for consumers to get what they need and at the same time ensuring their safety in this crisis time.

Research Methodology: The study under consideration is solely constructed from the data taken from respondents 
via administration of questionnaire as a schedule. The present study is a descriptive study which focuses mainly on the qualitative data. It is generally anticipated that the consumer's Socio-Economic characteristics will always impact level of awareness. Likert's five-point scale is being used to design the questionnaire, which aids to measure the impact of the virus on consumer behavior, factors influencing consumer buying decisions, marketing dimensions, social, economic and marketing impetus. In this regard, a hypothesis is framed which is statistically tested with $\chi 2$ test (Chi-squared test), which indicates the degree of association between two attributes. The study is confined to Bengaluru Urban limits with 200 sample respondents. Convenience sampling technique has been used with primary data collected through questionnaire and secondary data from articles in websites. Statistical test such as Chi-squared test, co-efficient of contingency and ANOVA is used to test the data.

\section{Sample and Sampling Technique}

Table 1. Sample decision

\begin{tabular}{|c|c|c|}
\hline Sl. & $\begin{array}{c}\text { Respondents } \\
\text { \&t occupation }\end{array}$ & No. (\%) \\
\hline 1. & Private Sector & 85 \\
\hline 2. & $\begin{array}{c}\text { Government service } \\
\text { Self-employed including }\end{array}$ & 30 \\
\hline 3. & startup entrepreneurs & 25 \\
\hline 4. & Business & 20 \\
\hline 5. & Homemakers & 40 \\
\hline & Total & 200 \\
\hline
\end{tabular}

\section{Objectives}

1. To study and analyse the impact of socio-economic factors influencing behaviour of consumers.

2. To understand the impact of Covid-19 on consumer behaviour.

3. To analyse factors such as economic, social environments, marketing and other stimuli that drives the consumer behaviour and the consumer buying decisions.

\section{Hypotheses}

1. The socio-economic factors of respondents will not determine consumer behaviour.

2. The presence of Covid-19 virus has not impacted consumer behaviour at Bengaluru.

3. Consumer buying decision process has no drivers.

4. Consumer behavior is not driven by economic, social, marketing and other stimuli.

\section{RESULTS}

Source: Authors compilation

Note: $\chi 2=$ Chi-square, "c" = Sq. rt [(x2/ x2 + N)] Where $\mathrm{c}=$ Contingency co-efficient,

$\chi 2=$ Chi-square calculated value,

$\mathrm{N}=$ Number of observations

All of the 10 characteristics indicate significant relationship however, the relationship between age and satisfaction is low so is age and gender.

Source: Field Survey

Note: SA - Strongly Agree, A - Agree, SWA - Somewhat Agree, DA- Disagree, SDA - Strongly Disagree

\begin{tabular}{|c|c|c|c|c|c|c|c|}
\hline No. & Characteristics & $\mathrm{x}^{2}$ & 0.05 & df & Result of $x^{2}$ & “c” & Result of "c" \\
\hline 1 & Age & 6.91 & 5.991 & 2 & Significant & 0.18 & Low Degree \\
\hline 2 & Education & 57.98 & 11.070 & 5 & Significant & 0.474 & High Degree \\
\hline 3 & Marital Status & 112.5 & 3841 & 1 & Significant & 0.6 & High Degree \\
\hline 4 & Gender & 8 & 3.841 & 1 & Significant & 0.19 & Low Degree \\
\hline 5 & Nature of family & 72 & 3841 & 1 & Significant & 0.51 & High Degree \\
\hline 6 & Occupation & 74.36 & 9.488 & 4 & Significant & 0.52 & High Degree \\
\hline 7 & Size of the family & 123.99 & 5.991 & 2 & Significant & 0.61 & High Degree \\
\hline 8 & No. of earning Members & 49 & 5.991 & 2 & Significant & 0.44 & High Degree \\
\hline 9 & Annual income & 40 & 7.815 & 3 & Significant & 0.40 & High Degree \\
\hline 10 & Annual Expenditure & 70 & 7.815 & 3 & Significant & 0.50 & High Degree \\
\hline
\end{tabular}

Table 3 reveals insights of impact of Covid-19 on consumer behaviour. These impacts vary from shift to value and essentials to homebody economy. Out of 200 respondents, 89 strongly agreed with the authors statements stated in the table followed by 66 agree, 10 said somewhat agree, 15 disagree and 20 strongly disagree. The ANOVA statistical test strengthen the fact that there exists significant variation in the data.
Economic Factors - Family income, Disposable personal income, Individuals discretionary income, Standard of living and Double Income. The economic factors vary from family income to double income. Out of 200 respondents, 90 of them strongly agree with the authors statements related to the economic factors followed by 65 agree, 10 somewhat agree, 15 degree and 20 strongly disagree. The ANOVA statistical test confirms the fact 
that there exists significant variation in the data which reaffirms income is main criterion in reshaping consumer behaviour.

Social Environment: Family Influence, Society Influence, Job and Colleagues, Friends and Relatives, Neighbours. These social environment factors vary from family influence to neighbours. 90 respondents out of 200 stated strongly agree over the mentioned statements followed by 70 agree, 10 said somewhat agree, 13 disagree and 17 strongly disagree. Majority of respondents opined that the near and dear ones are drivers behind the changing consumer behaviour. The ANOVA statistical test confirms the same.

\begin{tabular}{|c|c|c|c|c|c|c|}
\hline $\begin{array}{l}\text { Factors impacting } \\
\text { higher education }\end{array}$ & SA & A & SWA & DA & SDA & $\mathrm{T}$ \\
\hline $\begin{array}{l}\text { Shift to value and } \\
\text { essentials }\end{array}$ & 20 & 18 & 2 & 4 & 5 & 49 \\
\hline $\begin{array}{l}\text { Flight to digital and } \\
\text { omni channel }\end{array}$ & 15 & 8 & 1 & 2 & 4 & 30 \\
\hline $\begin{array}{l}\text { Shock to loyalty - } \\
\text { Supply chain disruptions }\end{array}$ & 13 & 14 & 2 & 2 & 3 & 34 \\
\hline Health \&t caring economy & 21 & 13 & 3 & 3 & 3 & 43 \\
\hline $\begin{array}{l}\text { Homebody economy - Not } \\
\text { comfortable resuming their } \\
\text { normal out of game activity }\end{array}$ & 20 & 13 & 2 & 4 & 5 & 44 \\
\hline Total & 89 & 66 & 10 & 15 & 20 & 200 \\
\hline
\end{tabular}

\section{Marketing and Other stimuli drivers \& consumer} behaviour: Product and service, Price, Distribution $\mathcal{E}$ communication, Technological considerations, Political considerations, Cultural considerations, Status in the society. These drivers vary from product service to status on the society. 85 respondents out of 200 stated strongly agree over the statements followed by 70 agree, 10 somewhat agree, 15 disagree and 20 strongly disagree. The ANOVA statistical test confirms the presence of variations in the data, which is an indication of external stimulus playing an effective role in determining the factors influencing the consumer behaviour.

Drivers of Buying decision prices: Problem recognition, Searching of Information, Alternatives Evaluation, Alternatives purchasing and post purchase behaviour. These factors vary from problem recognition to post purchase behaviour. 90 respondents out of 200 said strongly agree followed by 52 agree, 15 somewhat agree, 18 disagree and 25 strongly disagree. The ANOVA statistical test confirms the presence of variation in the data.

\section{CONCLUSION}

Understanding of consumer behaviour is most significant for every marketer. To understand consumer behaviour the factors that drivers the consumer behaviour has to be understood well. Covid-19 has severely impacted consumption of durable and non-durable products. The consumer behaviour is viable aspect and varies from time to time depending upon the changes that emerges in the society. Socio-economic drivers in addition to social environment and marketing factors in the present study impacted the purchasing behaviour.

\section{REFERENCES}

EY Future Consumer Index, June 2020

Accenture-COVID19-Pulse-Survey-Research-PoV.pdf, April 2020

Arun, M., Baraneetharan, E., Kanchana, A. and Prabu, S., 2020. Detection and monitoring of the asymptotic COVID-19 patients using IoT devices and sensors. International Journal of Pervasive Computing and Communications.

McKinsey \&t Co. (2020). Report on Consumer sentiment and behaviour

Abdul Brosekhan, A., Muthu Velayuthum, (2011). Consumer burning behaviour - A literature review, IOSR Journal of Business and Management, ESSN: 2278-487x, 08-16, www.academia.edu.

Global Web index, 2020 - Coronavirus Research Insights from Multinational Study wave 5

Seema Mehta, Tanjul Saxena, Neetu Purohit, July 2020, The New Consumer Behaviour Paradigm amid Covid-19: Permanent or Transient, Journal of Health Management, Volume:22, Issue 2, 291-301

Prabu, S., Velan, B., Jayasudha, F.V., Visu, P. and Janarthanan, K., 2020. Mobile technologies for contact tracing and prevention of COVID-19 positive cases: a cross-sectional study. International Journal of Pervasive Computing and Communications.

Phap Hai Thich, April 2019 - A Buddhist Approach to Consumption, Journal of Marketing Management 35(5-6), 427-450 
Anupama Sharma and Deepika Jhamb, 2020 - Changing Consumer Behaviour towards Online shopping -An Impact of Covid 19, Academy of Marketing Studies Journal, Volume 24, Issue 3, 152-160.

Swathi Vijay. (2015). Buying of customers with retailers in Maharashtra. Pezzottaite Journals, 4(1), 14581466.
Suja R. Nair. (2013). Consumer behaviour in Indian perspective, Himalaya Publishing House, 1-30.

Gorden, F.R., Castro, O., James J.M., Yani- De Soriam N.K.; Mirella M., Sigundsson and Valdmar. (2006). Analysis and social marketing. The case of environmental conservations, Publisher (NA) 